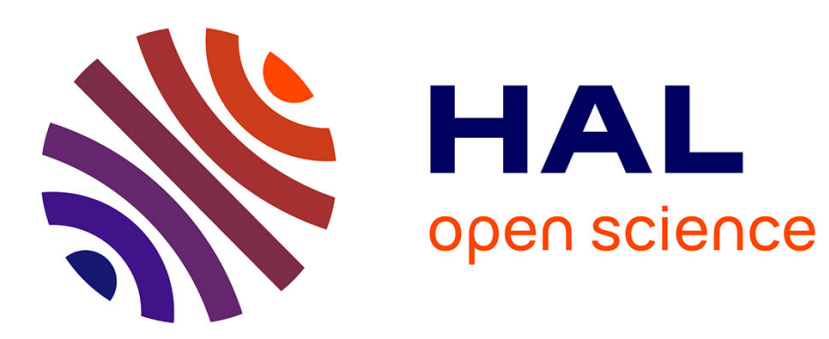

\title{
Japanese Economic Philosophy: An Introduction
}

Gilles Campagnolo

\section{To cite this version:}

Gilles Campagnolo. Japanese Economic Philosophy: An Introduction. G. Campagnolo. Revue de philosophie économique, 20 (1), Vrin, pp.3-34, 2019, 9782711652204. 10.3917/rpec.201.0003 . hal02365532

\section{HAL Id: hal-02365532 \\ https://hal-amu.archives-ouvertes.fr/hal-02365532}

Submitted on 25 May 2020

HAL is a multi-disciplinary open access archive for the deposit and dissemination of scientific research documents, whether they are published or not. The documents may come from teaching and research institutions in France or abroad, or from public or private research centers.
L'archive ouverte pluridisciplinaire HAL, est destinée au dépôt et à la diffusion de documents scientifiques de niveau recherche, publiés ou non, émanant des établissements d'enseignement et de recherche français ou étrangers, des laboratoires publics ou privés. 


\title{
Japanese Economic Philosophy: An Introduction
}

\author{
Gilles Campagnolo ${ }^{1}$
}

How economic philosophy developed in Eastern Asia is an issue that the Revue de philosophie économique/Review of Economic Philosophy has set to tackle. We open the debate with this first thematic issue on Japanese economic philosophy. A second volume will address China and neighboring areas.

International readers have scarcely heard of non-Western - in the present case, Eastern Asian - economic philosophy. We aim to bring to the fore the theoretical output of Eastern Asian economic philosophers. They often publish in their own language: for instance, authors featured in this issue usually publish in Japanese. Some do in English or French as well. Yet, when it is so, the articles in another language often display (at least slightly) different ideas. As a consequence, a (large) part of their works remains out of reach for the global audience in the discipline. Only Westerners who read Eastern languages have access and few do. Programs dedicated to "Japanese studies" throughout the world seldom bear upon topics such as those in economic philosophy, while the discipline would benefit from the wealth of diverse cultural backgrounds.

The aim of the Revue de philosophie économique/Review of Economic Philosophy in these two volumes is thus to remediate this situation. We will stress two aspects in our undertaking. On the one hand, we will highlight Eastern Asian economic philosophy in the historical perspective of its various local traditions. In this issue, for example, readers will discover who the founders of economic philosophy in Japan were through the words of their most contemporary representative, Yuichi SHIONOYA, recently deceased and whose texts we were granted permission to publish here. The authors featured in this volume are most likely little known to our readership, and thus it is the ambition of the Revue de philosophie économique/Review of Economic Philosophy to make them known to the community of economic philosophers. On the other hand, we will feature present-day authors and publications related to economic philosophy. The wealth of articles in this issue displays these two goals. ${ }^{2}$

\footnotetext{
${ }^{1}$ Gilles Campagnolo is a full research professor at the French National Center for Scientific Research (CNRS) in philosophy and economics (CNRS, Aix-Marseille University, EHESS, Centrale Marseille, Aix-Marseille School of Economics). He specializes in economic philosophy. He is an expert on European and Eastern Asian traditions, specifically liberalism. He was visiting professor and/or a "specially appointed professor" in China and in Japan (at the International research center for Japanese Studies "Nichibunken", Kyoto, at Hokkaido University, Sapporo, at Rikkyo University, Tokyo etc.). From 2013 to 2017, he coordinated the International Research Scientific Exchange Scheme "LIBEAC" for the European Union. Since 2019, he is PI and Coordinator for the International Research Network "Justice and Interest", comprising groups from the London School of Economics and the universities in Louvain/Leuwen (Belgium), Rotterdam, Helsinki and Lausanne. Gilles.Campagnolo@univ-amu.fr

${ }^{2}$ The Revue de philosophie économique/Review of Economic Philosophy opens its columns to academic contributions well beyond "the West", in line with programs developed by the co-directors of the journal. In particular, the present undertaking was given momentum by EU network "LIBEAC": the work leading to this invention has received funding from the European Union Seventh Framework Programme (FP7/2007-2013) under grant agreement $\mathrm{n}^{\circ}$ PIRSES-GA-2012-317767. Gilles Campagnolo created and coordinated LIBEAC (Liberalism In Between Europe And China) from 2013 to 2017, notably Beijing University, Tsinghua University (Beijing), Hokkaido University (Sapporo), among others. Approximately 60 scholars benefitted from this
} 
The region now called "Eastern Asia was formerly often called "the Far East", at a time when very different international relationships prevailed. The name, itself, was then tainted by different periods of discovery and a spirit reminiscent of past epochs when the study of Asian cultures was mostly the fruit of (sometimes adventurous) work carried out by missionaries, diplomats or scholars, most of whom were "specialists" of some Asian language or art (beginning with the martial arts). Their endeavors forged Asian studies per se. Some were inspired by a sense of attraction or admiration, others by fear or repulsion, while some were awed by a mix of all these feelings.

Although what still distinguishes present-day "areal studies" has evolved, the cultural traditions and linguistic, historical, and intellectual frameworks remain. Scholars of the past built such frameworks. Scholars of nowadays who deal with Japan are not all specialists of Japanese studies. They mostly contribute to their own field (here philosophy, economics and economic philosophy) and may meet issues related with Japan. This introduction, I hope, will help to shed some light on such disciplines with respect to Japan.

First (and for the sake of simplicity), the unity of the geographic area studied is the result of the (major) use of (originally) Chinese characters in the countries studied, with some extension. ${ }^{3}$ For instance, "economics" presented here is called jingjixue in Chinese, keizaigaku in Japanese, and in both cases is written 経済学. The characters that were put together for "philosophy" are 哲学 (Japanese: tetsu-gaku, Chinese: zhexue) and "economic philosophy” is expressed as 経済哲学 (Japanese: keizaï tetsu-gaku, Chinese: jingji-zhexue). ${ }^{4}$

The use of ideograms as a criterion for designating a geographic area naturally derived from this script, which carries a deep meaning anchored in cultural frames of thought. As the Japanese sociologist Masao Maruyama, notes:

[...] A Japanese native speaker who studied a little English, German or French while at University will find it easier to read, and will feel more acquainted with the philosophical works written in European languages than with Edo-style treatises by Confucian masters of those times, written in Sino-Japanese script [kanbun]. That makes for a major difference between the Japanese and the French erudite audience" 5 (Maruyama, 1996: xiv; our translation).

This assessment gets full illustration in the "documentary section" of the present issue.

international research staff exchange scheme. The present paper expresses the views of the author, who wishes to thank members of the network for their rich interaction. For more information, see the website: www.libeac.org The publication project started with the idea of only one thematic issue entitled "Economic Philosophy in Eastern Asia" for the Revue de philosophie économique/Review of Economic Philosophy, in addition to the collective volumes, such as Liberalism and Chinese Economic Development: Perspectives from Europe and Asia (2016). Due to the number of submitted papers that got positive reviews, we then opted for a two-volume set.

${ }^{3}$ In the case of Korea, this is obviously a different script, namely hanggul, yet ideograms are still in use for names and understood by scholars. Korea is evidently part of the area heavily influenced by Chinese culture, like some other regions: see the "Introduction" to the second thematic issue on "Eastern Asian economic philosophy". ${ }^{4}$ See the next section for the history of these terms.

See the last part of this introduction concerning transliteration used throughout the volume(s): for Chinese characters used in China, the so-called "pin yin" transcription is used, while older transcriptions are mentioned for names. Regarding the transcription of ideograms used in Japanese, the standard is the so-called "modified Hepburn" system: as a consequence, the reading of transliterated Japanese is somehow self-evident in English. French-language readers, please refer to the Appendix at the end of this introduction for more details.

${ }^{5}$ The kanbun script is the exclusive use of Chinese characters in Japanese while usually the Japanese language also makes use of two syllabaries (called hiragana and katakana). This "Sino-Japanese script" requires special training for Japanese and is usually related to texts older than the $19^{\text {th }}$ century. Kanbun basics are still taught in Japanese high-schools today, somehow like Latin in the West (albeit kanbun it is most often compulsory, thus keeping the link with old traditions in a world of otherwise "hyper-modernity"). 
There, we introduce the author, Yuichi Shionoya (1932-2015), one of the most eminent scholars of economic philosophy in Japan over the last decades. We dedicate a special section to him, with an introduction (in French). An obituary (in English) has been provided in homage by Bertram Schefold (Professor Emeritus, University of Frankfurt/Main), a dear German colleague of the late Shionoya while his Japanese colleague (and, like Schefold and Shionoya, internationally famous) scholar, Kiichiro Yagi, expresses a short view on the atmosphere in which "economic philosophy" first rose in Japan. This section then boasts two texts by Shionoya that are actually translated for the first time into a Western language. ${ }^{6}$

One text bears on the Interwar founders of economic philosophy in Japan, namely Kiichirô Sôda (1881-1927) and Kôzô Sugimura (1895-1948). ${ }^{7}$ The other text is based on the metaphor cherished by Shionoya that economics is a stream whose banks should be of particular interest to professional economists. Both texts are taken from the book that Shionoya dedicated to economics and ethics, which also includes a discussion of the philosophy of the Welfare-state (published by Tokyo University Press in 2002).

The many essays that precede the documentary section in this volume display the development of economic philosophy in Japan, which we can classify into two categories: one favors a historical perspective while the other discusses contemporary issues.

From a historical perspective, this issue lists a story of some misadventures (and sometimes downright errors) in the reception of the works by Adam Smith in Japan (Masataka Muramatsu), a narrative of a paradigmatic author fallen into disrepute for share in nationalist economic policies, Yasuma Takata (presented by Shigeru Kitajima and Hiroki Yokota) and an account of more recent reception of libertarian thought in Japan (Akio Fukuhara). Also on the contemporary side, economic philosophy dwells into the adaptation to modern-day economics of themes like economic freedom and socio-economics (Tsutomu Hashimoto). Those also embody the spirit in which to deal with economic philosophy and the history of economic thought.

In all the essays, philosophy and economics are interwoven with sociological or cultural concerns. Each author, in his or her own way thus makes a contribution to "Japanese economic philosophy", reviving a tradition inaugurated long ago, as Shionoya reminds us.

Within this framework, this introduction aims to provide Western readers with the minimal notions necessary for understanding matters in Japanese thought. The following pages assume that the reader is new to debates in (and on) Japanese philosophy.

The common thread throughout is not only convergence, but also the divergences with regard to how philosophical issues may (very) diversely be interpreted in the West and in Japan. We shall not survey the literature dedicated to that vast topic. ${ }^{8}$ In the present journal, the main focus is on "economic philosophy". Hence, it is necessary to recall the origin of the import of Western-style economics into Japan, and this shall serve as our starting point. Readers should also keep in mind that the impact of Western cultures - and, to begin with, the

\footnotetext{
${ }^{6}$ We thank for the authorization generously granted for translation into French, the Tokyo University Press and the heirs of Yuichi Shionoya.

${ }^{7}$ Note that the order of first (given) name and last (family) name are reversed in Japanese and in Western languages. For simplicity's sake, we restore the Western order everywhere, such that, for instance, the family names of these two economists are Sôda and Sugimura. Any deviations from this format are noted by the contributors to this volume, and sometimes capitals may be used for clarity to avoid any ambiguity.

${ }^{8}$ The interested English reader may refer to (Piovesana, 1997), (Blocker and Starling, 2001), (Porter and Ross, 2003) and, for more recent literature, to (Heisig and Uehara 2008) and (Heisig, Kasulis and Maraldo, 2011), (Hori and Curley, 2008) as well as texts compiled in vol. 3 Part 2 of (de Barry, Gluck and Arthur, 2001-2006). French readers, notice that publishing house Vrin (Sorbonne) issued a volume entitled "Textes clés de philosophie japonaise" (2013) wherein texts deal with Japanese general philosophy (metaphysics, phenomenology), though the volume lacks practical philosophy (political, moral and economic): see (Dalissier, Nagai and Sugimura, 2013).
} 
import of Western languages - has created the conditions for a fast-paced modernization process, where traditions seem sometimes to have become remote from contemporary issues even for the Japanese, as Maruyama rightly wrote in the passage quoted above. Western readers may feel even more at odds with a different world where the ideas originated in their own world, the West, have been adopted and adapted in ways unfamiliar to them. The next sections aim at giving a broad outline of the intellectual history of economic philosophy in Japan, and thus at illuminating the path for the readers.

\section{Western philosophy reaches the shores of Japan}

We shall first clarify the framework wherein "modern", or "Western-style", philosophy and economics were adopted and/or adapted to local needs after reaching the shores of Japan.

Japan was the first country to become modernized in Eastern Asia, and even, more generally, outside of the Western world. ${ }^{9}$ This was due to so-called "Meiji enlightenment", ${ }^{10}$ a revolution from 1868 on. In reality, this phenomenon had started some 15 years earlier, while the so-called "bakufu (幕府) Shogunate" regime of the Tokugawa family lived its last two decades under pressures from Western powers to open its harbors to trade and diplomatic representation; the regime had virtually closed access to the empire of Japan after taking power in 1603. The (almost) full closure (sakoku 鎖国 in Japanese) lasted for some 250 years, keeping a lasting peace (天下泰平 tenka taihei) ${ }^{11}$. After that, one may speak of 150 years of "Modernization", to use a simple term for a complex phenomenon, or 160 years since doors opened: for instance, the first reciprocal diplomatic representations between France and Japan dated from $1858 .^{12}$

In a nutshell, the Japanese sought from the Europeans new ideas and techniques, as well as government and investment strategies, and the Europeans obliged by conveying indispensable underlying values. While European powers ruled most parts of the world, the Japanese pulled the rug out from under their feet, so to speak, by adopting and adapting the same efficient methods and values in their own name. Countries that aimed to escape European power were left with no other choice but to follow Japan's model. The Japanese thus preserved their independence by bringing about major changes at home, from their political regime (by achieving the Meiji restoration of imperial power) to everyday lifestyles and their entry into industry and mass-production. Japan was successful in those reforms. Taking an accelerated remedial crash-course in modernization, Japan became the first and most prominent non-European power for one century by all standards. Japan would, in turn, impact neighboring non-European parts of the world, where it would, for better or worse, learn to rival with Western powers, playing strong cards and tough games, including rising nationalism and World War II - horrors which were both committed and suffered by Japan.

Forces at work to spread modern ideas on production included liberalism and its adverse currents of thought (Marxism, various kinds of socialism and anarchism, etc.); capitalist

\footnotetext{
${ }^{9}$ Besides any other consideration of texts submitted from Eastern Asia within deadlines by potential contributors to the Review of Economic Philosophy, this historical precedence suffices to legitimate the choice of the Review to dedicate this first issue to the Japanese case.

10 明治 (in Japanese: meiji) means “Enlightenment” in the sense of the French, or the Scottish period of scientific and political history of the $18^{\text {th }}$ century.

${ }^{11}$ The symbolic end of that period was marked in 1853 by the presence of the armada of "back ships" under the command of US commodore Perry in the Bay of Tokyo (then called "Edo").

${ }^{12}$ Hence, the sesquicentennial was celebrated in France in 2018 with a twofold interpretation: either as the $150^{\text {th }}$ anniversary since Meiji began, or as the 160 years of Franco-Japanese diplomatic relations. A full-fledged campaign of artistic and cultural events labelled "Japonismes" aimed to bring Japan closer to the French.
} 
industrialization and militarization were also on the rise. All in all, Japan trod its modernization path, leaving behind the technical features of its traditional society: this process was labelled "Westernization" since it was grounded on doctrines originated in Europe. Moreover, the "Western" view of the world spilled over from the empire of the Rising Sun to other areas of Eastern Asia: Japan often served as a gate for Western ideas to enter the Middle Kingdom of China, whose intellectuals and revolutionaries often began their discovery of the world and newer ideas in the natural and social sciences, in the arts and in modern politics, on Japanese shores (Kobe or Nagasaki, to mention only the two harbors already open to them under the pre-Meiji Tokugawa regime).

The query whether Japan was still Oriental, or not yet Western raised many doubts about Japanese identity. Blocker and Starling state strikingly that the Japanese offered no reluctance to the introduction of new Western ideas, in the sense that they did not seek to maintain some previously existing "Oriental self" (in sum, they saw no "self" to maintain). So they did not see themselves as Oriental. Yet, since the idea of the significance of the proper self is a very European marker, they were not Western either. In the end, they were neither one nor the other: "in other words, Japan is nothing" (Blocker and Starling, 2001: 192).

Before truly coming in contact with the new subject matters of Western academic disciplines and their specific conceptual vocabulary, the Japanese had simply no name for them. A quantity of words had to be coined. Firstly, names to designate subject-matters as such: for instance, the names "philosophy" and "economics" seen in modern, "Western-style" guise. Ideas were already imported by the Japanese before the official end of the bakufu in 1868. A tradition of the controlled import of knowledge of so-called "Dutch studies" (蘭学 rangaku) was cultivated. During the 1850s, Japanese scholars started to realize that the English language (and not Dutch) was most commonly used among Westerners to understand one another. It was insufficient to translate works from Dutch into Japanese. It was also insufficient to deal about techniques (medicine or strategy) for transmitting in-depth Western knowledge. English, German, French languages were now paid attention. It became necessary to label in Japanese the "new sciences" to help their compatriots understand the fundamental ideas thus discovered. Modernization was not only about importing techniques, but about more fundamental notions, even about views of the world.

An illustrative example is provided by one major character of Japanese modernization, Ôgai Mori (1862-1922). An army surgeon, Mori studied four years in Germany. His father was a medical doctor who had studied Dutch medicine, while his grandfather practiced Chinese medicine. Mori himself served at war, for instance against Russia (1905). He translated many works from the German: Clausewitz's classical Vom Kriege (On War), medical treatises and philosophical works ${ }^{13}$. He was kin to Amane Nishi, of the prior generation, whom we now mention since Nishi coined the Japanese word for "philosophy".

If one may generally speak of "philosophy" as a Weltanschauung that conveys civilizational traits (be they Japanese, here, Indian or Chinese, French or German elsewhere), this is not enough to embody the "scientific" point of view that European philosophy tends to promote, from Descartes to Auguste Comte, from John Locke to Herbert Spencer - to quote only two names that would become very popular in Japan. In this sense, "philosophy", based on the ancient Greek notion of logos, or a reasoned discourse, is a methodology based on systematic criticism to raise notional problems, which evolved into an academic discipline. Thus, "philosophy" in a restricted, delineated perspective is but one "way of thinking", but it is also the reflexive attitude that distinguishes it from other such ways and provides it with its

\footnotetext{
${ }^{13}$ For example, among many texts: Max Schasler, Kritische Geschichte der Aesthetk. Grundlegung für die Aesthetik als Philosophie der Schönen und der Kunst. I: von Plato bis zum 19. Jahrhundert, Berlin, Nicolaische Verlagsbuchhandlung, 1872). Mori also translated Shakespeare (from a German version). He changed the style and rhythm of the phrase in Japanese literature.
} 
efficiency. In that sense, as Chômin Nakae ${ }^{14}$ famously and provocatively put it in 1901: "From Antiquity to our days, there has never been any philosophy in Japan". ${ }^{15}$

Nakae attempted at naming the latter new discipline based on a scientific approach with the word "rigaku 理学", which makes good sense given that $r i$ (理) means "principle", coming from a long tradition anchored in Chinese thought. Nakae articulates his "doctrine of principle" in his work titled A philosophical Quest (理学鈎玄 Rigaku Kôgen). It is probably less well-known than his Dialogue between Three Drunkards or One Year and a Half and its sequel: One Year and a Half. A Sequel, the most cited work when his philosophy is debated. In his Quest, Nakae never forgets to interweave wit and a joyful attitude towards life - maybe taken from his interest in French philosophy and mindset? ${ }^{16}$ He describes how reflection occurred gradually in the minds of men, and not at all from the start, when they only "ate what they could gather and drank from rain with their bare hands, like wild beasts". ${ }^{17}$ The word rigaku 理学 was not adopted, however.

Actually, as I already hinted at, one word was already coined earlier on, by another thinker of this period of modernization, Amane Nishi. ${ }^{18}$ Nishi conscientiously imported the ideas of Auguste Comte and John Stuart Mill into Japan. He knew about other currents of thought and voluntarily favored their "positivistic" attitude. As a consequence, the Japanese first knew of Western philosophy through these views and not through earlier metaphysics. Things happened as if the Japanese would start learning of Western thought with what Comte regarded as the "last" stage of the development of thought (the first one being the stage of religion, the second that of metaphysics and the last one being "positivism" Comte put forth).

Nishi coined the term "philosophy" (哲学 tetsu-gaku) in 1862 . He was under the inspiration of his studies in the Netherland. His interests lay in psychological studies, the philosophy of French positivism - as just indicated, he saw in it a development of Cartesian views by Comte and modern European thought through the lens of Mill's ideas. For Nishi, there was the chance to provide a new classification of all sciences to be characterized for modernization that Japan had so much use for. Nishi had a pro-active mind and very practical in that sense for a philosopher - actually he would end his career as very high official of the regime. Nishi's Hyaku-ichi Shinshuu (One Hundred and One New Theories (1862) represents precisely the attempt to introduce positivistic views with the new discipline under a new name.

Briefly, the story of Nishi's education and travels to the West goes as follows. After learning Dutch and English, Nishi was sent to the Netherlands among the first nine young Japanese students sent to Europe by the Japanese government in 1862 . The trip was first scheduled to America, but as the American Civil War just started, the plan was changed and the trip was re-oriented towards Europe. The study-squad, so to speak, was made of five military men, two medical doctors and two researchers of the recently founded "Institute of

\footnotetext{
${ }^{14}$ Well-known under this pen-name, his real name was Tokusuke Nakae (1847-1901). In his crusade for justice, he chose to change his first name to Chômin, which means "the people", to become Nakae Chomin (in Japanese order where name comes first (one usually speaks in Japan of MORI Ôgai and NISHI Amane).

${ }^{15}$ Quoted from (Blocker and Starling, 2001, p. 1). In China, the same question was raised as Western philosophy was introduced largely following a Japanese detour. It was formulated: "was there ever genuine Chinese thought of a kind equivalent to that in the West?"

${ }^{16}$ That may to some extent have included the famously-known French joyful attitude towards life (known as joie de vivre): see (Dufourmont 2009).

${ }^{17}$ The development that leads to later civilization and the ability to reflect, requiring spare time, which beasts do not know of. The idea most probably originate from reading the book La philosophie by French anthropologist André Lefebvre (1884), as Haruo Miyamura points out in Rigaku Kôgen (Miyamura, 1989: 152-158). Nakae learnt French first in Nagasaki (under the missionary Frère Petitjean) and then in Tokyo with the official interpreter of the Imperial court. Later, Nakae went to France (1872-1874) and met with French Republicans.

${ }^{18}$ The name of Amane Nishi (1829-1897) is definitely the main name associated with the voluntary systematic introduction of Western philosophy in Japan.
} 
research on foreign books" (bansho shirabesho). Nishi was one of those last two young men ${ }^{19}$. During his stay, the Japanese government requested that he would study in Leyde under the professor of economics, Simon Vissering. The discipline of economics had thus, from the start, been identified by the shogunate government as one source of knowledge important for modernizing Japan. This is documented since Nishi sent letters to the Rectorate of the University with explicit requests to be authorized to follow lectures, on the one hand, in law (natural, international, constitutional), economics and statistics, politics and diplomacy, and philosophy, on the other. This coupling of the humanities and the social sciences was present from the start of Japanese modernization. Nishi himself explained:

[...] I would also wish to study what you [tr. at the University] call philosophy. I think that what Descartes, Locke, Hegel, Kant and others have told and put forth in the past, none of that pertains to religious thought that is forbidden by our law [tr. in Japan]. Although philosophy may indeed be extremely difficult to learn, I am convinced that it is absolutely indispensable to study it in order to develop and cultivate our country [tr. Japan]. This is why, despite all foreseeable hardships, I wish to learn it, at least partially as much as possible ${ }^{20}$.

Nakae and Nishi had, interestingly, diametrically opposite perspectives in many ways, not the least politically. Nakae would come to be called "the Rousseau of the Orient", not only for his translations of the French thinker, but also for his praise of popular sovereignty and his support of incipient socialism in Japan; he was eventually exiled from the capital city for his militant activities. Nishi, on the other hand, did not only coin the term that remained in use for philosophy, but was also an active and fully engaged participant in modernizing his country. He ended his career as a very high dignitary of the imperial state.

Together, Nakae and Nishi illustrate the paths that incipient Japanese philosophy could and would take. Nakae's wording prevailed in another case, that of esthetics, where the word he coined remains to this day (美学 bigaku) in the way he presented it in his work of 18831884 based on a translation of L'Esthétique by the French thinker and Republican militant Eugène Véron. Nakae possibly had the chance to meet Véron in the city of Lyons, where they both dwelt at the same time, and where Nakae acquainted himself with Republican circles during those first years of the Third French Republic when Nakae was in France (January 1872-May 1874).

Mentioning all this influence from France, it may appear to the reader that French thought operated much of the change brought by Japanese early philosophers. That would not be false, albeit excessive. Chance also played its role, like when the country chosen for the Nishi-mission was changed to the Netherlands from the United States, where it was first scheduled to take place (and became impossible for some reason). One should also stress the major philosophical influence of Great Britain as well, especially the social evolutionism of Spencer, and later progressive views illustrated by Bertrand Russell. There were many more thinkers, especially on the Continent, whose ideas were imported to Japan, whether they supported vitalist views, like those of the Frenchman Henri Bergson, or Lebensphilosophie, such as the German Nobel-Prize winner (in literature) Rudolf Eucken. Many other schools of thought were imported into Japan, such as Neo-Kantian schools of Rickert, Natorp or Cohen (developed in South-Western Germany and in Marburg), Neo-Hegelian or phenomenological (Husserl, Heidegger) schools of thought. The latter inspired the first so-called "genuinely national" Japanese philosophy led by Kitarô Nishida with the so-called "Kyôto School"

\footnotetext{
19 That was in itself an achievement. In the next generation, Mori (mentioned above) failed to pass the examination to benefit from that same grant. Mori enjoyed one from the land-army (rikugun) to study strategy and medicine in Germany. As mentioned, Mori was to bring much more from his trip to the Japanese mindset.

${ }^{20}$ This quote from Nishi is taken from (Takashi Koizumi, 1989: 43-44, our translation).
} 
(Kyôto-gakuha). Other closely related schools of philosophy, such as that of Tetsurô Watsuji, were also developed. This is not the place to expound on these points: we shall focus rather on economic philosophy and, for that purpose, on how economics, in turn, reached Japan and how "economic philosophy" emerged stricto sensu and expressis verbis.

\section{"Western" economics reaches the shores of Japan}

The "Western" science of economics reached Japan from the very first moment of encounter between the Japanese envoys and their European professors: the above-mentioned lectures that Nishi attended by Vissering in Leyde are proof enough. Soon, many other channels were opened and the trend flourished once Japan entered the Meiji period; liberal ideas brought about the rise of circles like the Meijiroku shakai (the society of members of the Year 6 of the Meiji era, that is to say 1874, also known under the short acronym of 明六者 Meirokusha) ${ }^{21}$. Innumerable works were translated, and the reception of the ideas of Smith became commonplace among Japanese economists, while textbooks became widespread, like the one written by John Elliott Cairnes. Obviously, the effort by Japanese authorities was enormous for building up not only the economy, but also the field of economics. This produced a demand for economic studies that would, in turn, bring awareness that this development raised many concerns. The government's efforts to spread of economic ideas finally resulted in the emergence of "economic philosophy" as a field per se. How should that wording be understood then, and first of all, called by the Japanese? That is partly what this thematic issue explores.

At the onset of this process, the word coined for the discipline of economics was highly influenced by British and German perspectives, the countries from which the Japanese had imported the discipline. Like philosophy and the natural sciences, there were different attempts to name the discipline - in physics for example, the term 格物学 (kakubutsugaku) was put forth by Nishi, but it is the later-coined, 物理学 (butsurigaku) which prevailed and which is still in use today. "Western" economics also got its name and the science thus labelled accompanied the rise of Japanese economics, building one of the main industrial powers of the world: the Japanese coined the word keizaigaku with the characters 経済学. The term results from combining 経 and 済 (学 simply means “study” or academic discipline), short-hand for a longer four-character proverb 経世済民 (keiseizaimin), which combines the two mottos "govern the country" (国を治める kuni wo osameru) and “protect the people" (人 民を済 jinmin wo sukuu). Its introduction into the curricula of Japanese universities was a deliberate process, supported by authorities (as for instance Soyeda 1893 documented), and the term newly coined came to exclusively mean Western economics.

The word "economic philosophy" appeared half a century or so later. During the time that had elapsed, a new era followed that of the Meiji: the short-lived Taishô era (1912-1926). Japan had become the main power of Eastern Asia. The Meiji government, for example, defeated China in 1895, thus winning its first war ever against China (if one does not count the resistance against the twice-attempted Mongol-Chinese invasion in the $17^{\text {th }}$ century $)^{22}$. Japan used modern weapons, technology and strategy. In neighboring areas, Japan invaded and colonized Korea in 1910, and extended its maritime power by swallowing up Taiwan,

\footnotetext{
${ }^{21}$ The journal of the movement, titled 明六雑誌 Meiroku Zasshi (the Journal of the Sixth Year of Meiji) published the works of these intellectuals - among many others, for instance, the Treatise on the Intellect (知説 Chisetsu by Amane Nishi, whom we shall further present below.

${ }^{22}$ The 1895 Japanese victory initiated the period called the "Chinese break-up", representing the last decades of the Manchu dynasty in China.
} 
(then known as Formose). Japan built a fast-expanding empire. Among the winners of World War I, Japan was rewarded with its first stronghold on continental China by taking over the formerly German-influenced Shandong peninsula around Qingdao ${ }^{23}$.

The time when the Japanese stayed within its borders and traded only with Chinese and Dutch merchants in the restricted areas of Kobe and Nagasaki was long gone. Naval dockyards for civil and military ships had been built (by the French in Yokohama, for instance), and Tokyo became heretofore (since moving from Kyoto in 1868) a major capital on the world map, even in the eyes of Western governments. Before World War I, the Japanese often favored Germany or Austria, feeling closer to their conservative imperial views than the republican France (which had, moreover, supported the earlier defeated bakufu until the last fight). Japanese Liberals would favor the UK and the US. Their top academic institutions were copied, and new institutions were built to bring power and glory to the rising sun.

Japanese intellectuals imported a vast quantity of knowledge from their travels during the period from the 1850s until the 1920s. From Europe, they brought back scholarship gathered from Britain and continental Europe or America, either directly or indirectly, since Japanese translations that introduced modern thought (in Japan as well as in the rest of Eastern China, beginning with China) were often re-translations from an English version of a Continental work; these were called compendia, digests or rewritings, and so on.

Questions such as how "Western" economics was introduced into Japan, how the currents of thought of Marxism played a major role, or how what the Japanese called "modern economics" (kindai keizaï gaku 近代経済学) developed, from the 1930s and especially after World War II to our days, all deserve their own history. Such history, however, has been written, so we shall not repeat it here ${ }^{24}$.

Textbooks are a useful tool for examining such history, as they provide a sampling of all currents of thought, from liberalism to collectivism. The most widespread textbook of Classical political economy, by J. E. Cairnes, was mentioned above. Marxism also impregnated a large part of the Japanese academic world, however it never seriously expanded, in contrast with China. ${ }^{25}$ Translations sometimes started from mere transcriptions of texts in English, with Japanese scholars in European universities copying excerpts later to be translated. The archives centers that we have visited in many university libraries of Japan keep these deeply moving examples of keen scholarship and major painstaking work accomplished by Japanese scholarly envoys.

Texts translated into Japanese from English were themselves sometimes already translations from another European language, such as German or French. The Japanese scholars in economics often learned German instead of English, a tendency that would later depend on political ties with the various powers. They also often kept to one foreign language,

\footnotetext{
${ }^{23}$ The Germans had set up a beer industry there, the Tsing-Tao beer; it has been internationally well-known ever since, partly thanks to the Japanese brewery industry that made it its own for a third of a century.

${ }^{24}$ For an overview, see, for instance, (Sugiyama 1994) or (Morris-Suzuki, 1989) a widely-used basic history of Japanese economic thought. See also the many monographs or collective volumes by Japanese historians of economic thought, who often deal with their topic in addressing in-depth one facet of the many only hinted at in this introduction. The reader will find many titles in English in series dedicated to the history of economic thought by specialized publishing houses.

${ }^{25}$ That is why the role of Marxism in economic philosophy in Eastern Asia shall rather find its place in the second volume of the Review of Economic Philosophy dedicated to economic philosophy in Eastern Asia. This is not to say that its influence in Japan does not deserve to be stressed, starting with famous names such as Michiyo Morishima. But the Review had to divide subject matters as best possible. Similarly, the role of Hayek in Eastern Asia will be illustrated in the second volume, with a text about "Hayek in Korea". The reader is reminded that our text "Hayek in Japan" was published in volume 17/1 of the Review of Economic Philosophy (Campagnolo, 2016b).
} 
which had the disadvantage of narrowing their horizons, as well as cutting themselves off from a useful way of checking the value of the translations they used. Admittedly, given the long chain of translations and interpretations, much of the original meaning was lost in translation. Losses and/or changes in content were thus an inevitable price to pay for the massive adaptation of such ideas into the local language. Moreover, adaptation to the Japanese conceptual framework also considerably modified content, sometimes to the point of leaving almost nothing from the original untouched. Western readers are often surprised by what actually reached the final Japanese reader (of that period in time, naturally), albeit an erudite scholar.

Let us pause here to recall that the ideas put forth since the European Renaissance, and even from the Ancient times of Rome and Ancient Greece, were swallowed up by the Japanese over a couple of decades, at most a half century (the period 1860s-1920s). How could such a concentrated overload of ideas not result in a mix resembling something like a "tomato purée", to use a culinary analogy? We must also remind the reader of the Japanese framework in which such imported ideas had to be made to fit. Let us, first of all, recall that economic concerns were formerly regarded as low-class in samuraï Japan. To work as a merchant was indeed higher than working as a peasant (leaving aside the stratum of social outcasts, the so-called burakumin), but buying and selling, in general, was inferior to any other kind of social activity.

Since the $17^{\text {th }}$ century, however, a whole body of knowledge has been built out of interest for the increasing number and power of those sellers. Indeed, the Japanese had worked out some forms of contracting and buying and selling that paralleled a few Western traits of nascent capitalism ${ }^{26}$. Such times are recorded, for instance, in the stories of merchants, like those narrated by the great writer Ihara Saikaku. His narratives are testimony of that development in the Western area of Japan - the Kansaï region - including Matsuzaka, Kobe and Osaka, wherefrom major Japanese companies would later emerge. The vast body of such literature, neither necessarily related to eventful narratives nor to abstract knowledge, emanated in Japan from the rising merchant class (while in China, such literature more often originated from the imperial state power of the moment). The new discipline imported from the West was as opposite in abstract and universal characteristics as were the Japanese and Chinese "economic" writings dating back to before the existence of Western economics ${ }^{27}$.

This is not to say that Japanese early ethos would fully parallel the European development of capitalism based on free enterprise. For instance, Morishima stated:

A remarkably idiosyncratic ethos prevails in Japanese society, and as a result of these ethical feelings Japanese capitalism has to a considerable extent deviated from the typical free enterprise system. The question is [...] why the possessors of this kind of non-Western attitude came to gain such control over the industrial techniques produced by the West. (Morishima, 1984: viii)

Part of the answer lies in the religious behavior that played a role along the centuries as

\footnotetext{
${ }^{26}$ Some historians (and a mathematician economist who tackled the issue from sheer interest: Morishima 1984) see the following feature as decisive: in the Middle Ages, both Europe and Japan were ruled by feudal structures. There, faithfulness to one's word was a most revered value between competing lords, who built domains upon that basis. So-called "free cities" were also major players in the birth of an early capitalism in both regions of the world (Italian seaports, Western Japanese cities like Matsuzaka, Osaka, and so on); early entrepreneurs and bankers built structures that would later be ready to serve modern industry. That theory is often supported by stressing a specific Japanese ethos in the face of China, where an altogether different historical form of development prevailed characterized by long periods of authoritarian imperial rule, followed by shorter periods of great turmoil, leaving no hope but in a new despot). See also (Powelson, 1997).

${ }^{27}$ The term 政治 (Japanse seiji, Chinese Zhengzhi) changed meaning is still in use today to say "politics” at large.
} 
Max Weber notoriously pointed. Some facets of Christianity, on the one hand, along with Buddhism, Confucianism and Taoism imported from China approximately simultaneously in the $6^{\text {th }}$ to the $8^{\text {th }}$ century, on the other. The principle of "virtue" (that has to be followed), displayed in the character 理 (Chin. $l i$ and Japanese $r$ ), was fundamental - and would pervade thought, especially in its reflexive attitude towards economics (we shall come back to this later). But there was also clearly a nationalistic stand, as well as an anti-intellectual mark in Japan's evolution. It is not coincidental that a culture of immanent views lying far from any Western-style "abstract" reasoning would appear as the general background upon which the reception of Western ideas and, among others, economic ideas would have to prevail in Japan. Practical structures (banking, entrepreneurship) indeed existed in early-modern Japan ${ }^{28}$. As a structured feature, practical goals would always prevail, even when respect was paid (at least, at face-value) to imported theories.

As far as economic doctrines are concerned, there are many strong illustrations of Japan submitting its foreign imports through a tedious process of sifting and refining. Much like its imports from earlier epochs - writing from China, pottery from Korea, and so on - the modern sciences that Japan imported from the West were adapted to fit its own local use. But could that not be said about most countries? And is that not true of most major civilizations?

What makes the Japanese case uncharacteristic in that regard is still probably related to the following paradox: while the Japanese imported almost everything from other cultures, they are also proverbially known for their unique specificities. Centuries of the closure of its bordures help to explain that they developed "national", almost "family-like", attitudes and behaviors specifically of their own. There may be more to it. In a sense, the void space that not only techniques, but concepts, knowledge, ideas etc. came to fill from the outside were engulfed in the Japanese civilizational "space" as if that space was void, and meant to be filled.

The purpose of adapting foreign ideas is deliberate, hence the need to reserve a space to "welcome" these ideas, in order to "digest" them, so to speak. The Japanese civilization thus developed thanks to an inner ability to clear enough room to adopt and adapt not only the techniques, but also the spirit of other cultures, without "truly" incorporating them. The whole issue is what "truly" may here mean. What is clear though is that neither the Chinese formerly, nor the Westerners, may easily recognize the features coming from their own respective worlds in Japanese guise. In other words, the Japanese "newer" version of imported views is tailored to the needs of the Japanese (and gain interest mostly, if not exclusively, in that regard). It serves no other functioning structure (be it Buddhism and neo-Confucianism from China or liberalism, Marxism and nationalism from Europe). Japanese are masters in the refined use of all sorts of doctrines and ideas, but they do not ever commit themselves to any ${ }^{29}$.

\section{Japanese economics rises with the Japanese economy and "economic philosophy" emerges}

The slight digression that concludes the previous section was made in order to explain in this section the deep change that took place within the framework of Japanese academic

\footnotetext{
${ }^{28}$ When meeting the modern West in the form of, say in 1853 , the "black ships" of commodore Perry, Japan already had ready "sophisticated banking and exchange practices, commercial law, and bureaucracies capable of handling advanced economic policy" (Powelson 1997: 2).

${ }^{29}$ To illustrate that point with daily life images: envoys and entrepreneurs of the Meiji epoch, much like those of today, can at will adopt Western clothing or recite Buddhist sutras, but put back on their kimonos at the end of the day They see absolutely no contradiction between acting in these different ways as long as they are beneficial, or may only potentially be, or appear to be beneficial: since they may work, let them be tried, a pragmatic stance that impregnates the so-called "Japanese mind".
} 
institutions, first in the 1870 s and then in the 1920 s.

With positivism brought by Nishi, liberalism and utilitarianism were at a par since the he imported the views of Mill as well as those by Comte. Nishi was not alone: the generation that brought into Japan such ideas was nicknamed the “Enlightenment thinkers" (啓蒙家 keimôka). They soon split between the latter and another trend, much less liberal in thinking yet eager as well for modernization but advocating protectionist views that are part and parcel of German imported influences.

To put it in a nutshell, theories were always regarded as tools by those in power, which meant that the tools had to be sharp to cut through old customs. Imported methods could be made subservient to the rise of the nation's economy as well as military power, for instan,ce this paving the way for the later rise of nationalism. Signs of approval of the import of foreign views are thus at the same time, tokens of an open-minded spirit of the time, of interest in earnest for a new scientific faith, as well as of a pragmatic wish for practical use and the nation's service.

A major push in all these directions at the same time was given by Yukichi Fukuzawa Yukichi in his Call to Study (Japanese「学問のすすめ」Gakumon no Susume) as early as 1876. ${ }^{30}$ Japanese intellectuals acted as catalysers, helping to establish the first universities, starting with "Keio college", which Fukuzawa founded in Tokyo. This was soon imitated, and the Meiji Emperor established the University of Tokyo, followed by the famous "seven Imperial universities" across the country. Private universities and colleges founded by foreign missionaries were also granted permission by the Emperor; some remain to this day the major learning institutions of Japan.

Intellectuals- much like their famous ancestors of the Japanese study-abroad movement Nakae and Nishi - followed in cohorts and, decade after decade, systematized connections with the West. In this perspective, the eclecticism of "Western recruits" among the great thinkers has been remarkably varied. We have quoted a few names, but specialists were also "imported" to Japan as professors of imperial universities, such as Ernest Fenollosa at Tokyo University $^{31}$ or William Smith Clarke at Hokkaido Imperial University, at Sapporo, the capital of the late-colonized and developed Northern island of Hokkaido whose landscapes unmistakably evoke the American Middle West ${ }^{32}$.

In the 1920s, the Faculty of Economics became independent from the Faculty of Law and Politics at Tokyo University and at Kyoto University, which had been their harbor for almost half a century. That trend was only natural, reproducing what had happened two or three decades earlier in Germany and France, and would become an institutional pattern for many developed countries: there would be independent faculties for law on the one hand, and for economics on the other hand - while they naturally continue to interact in order to raise the future elites in the top universities, the independence gained by economics was crucial for the development of that discipline in Japan (like everywhere else), bringing it full academic recognition for the first time - in other words, a grand academic revolution for Japan. This modification to the academic landscape of Japan is still felt today. The decision was also strategic, since the governmental hoped to find solutions against economic evil (poverty and unemployment) at a time when the effects of military demand from previous decades (including World War I) was temporarily lacking. This situation caused unemployment. In the eyes of many, it also displayed how the economy and the military were linked (which comes

\footnotetext{
${ }^{30}$ This chapter is dedicated to China, not Japan. On Yukichi Fukuzawa (1835-1901), the reader may consult (Kumagai 1998).

${ }^{31}$ Ernest Fenollosa (1853-1908) was a professor of philosophy and political economy at the (then Imperial) university of Tokyo.

${ }^{32}$ William Smith Clark (1826-1886) was an American scientist recruited to build up the Agricultural College that was to become Hokkaido University, upon the model of what he had done in the United States.
} 
as no surprise in many modernizing countries).

In 1923, this independence between faculties coincided with the $200^{\text {th }}$ anniversary of the birth of Adam Smith. Both events were celebrated and greatly deepened Japanese research on Smith: on the one hand, Smith became a new symbol of support for liberal economics; on the other, it gave the Japanese the chance to study the thinker, introduced during the first years of the Meiji regime, for what he was: a major philosopher. His science of jurisprudence and moral philosophy were as pertinent as ever (?). At the same time, Japanese thinkers prided themselves on spreading the difficult words of German philosophy, especially those of the Neo-Kantian schools of thought. Nishi's hopes of bringing Western philosophy to Japan, as quoted above, were thus not in vain.

Moreover, with Japan's turn towards nationalism, famously known as tenkô in Japanese, the "conversion" where many intellectuals turned to nationalistic views. In the 1930s, a genuinely national philosophy would develop in that spirit, notably but not only within the socalled “Kyoto School of philosophy” 京都学派 Kyôtogakuha. Such a nationalistic philosophy would have less to do with economics than other critical currents of thought, and more to do with a transcultural understanding of individualism (Altobrando, 2016). Such views were alternative to what the most liberal among the Japanese would hope for, however. Nationalistic tendencies brought thinkers like Yasuma Takada to illustrate views related to economics.

While socialist thinkers were isolated or "converted", a real trend of alternative thought emerged with ideas brought to the fore by two professors from Hitotsubashi University, namely Kiichirô Sôda and Kôzô Sugimura. Both unfortunately were to die young. Yet, they set forth the idea of "economic philosophy" in Japan. These founders were economists, both inspired by German neo-Kantian schools. One may say that their most important contribution was founding the field of "economic philosophy" in Japan and that their readers and followers made a heyday of its first period of existence and success of the new discipline.

Like the founders of new disciplines before them, Sôda and Sugimura coined new words: with the characters for economics and for "philosophy", the field of "economic philosophy” resulted as 経済哲学 (Japanese: keizaï tetsu-gaku). Another word that Sugimura attempted to promote under the influence of German Neo-Kantian axiological theory resulted in 経済倫理学 (keizaï rinrigaku), evoking "economic ethics". One may find these words as entries in dictionaries of economics of the 1920s. The first word remains in Japanese vocabulary (keizaï tetsu-gaku). In this volume, Yagi expresses in a note for this issue the atmosphere of the first rise of "economic philosophy" in Japan, while the late Shionoya recalls the role of these two scholars, as it has sometimes been unfairly forgotten. Shionoya does justice to them with a superb text translated into French in this issue. We refer the reader to that section.

As a consequence, Japanese dictionaries of economics of the 1930s included the entry "economic philosophy" and the names of its founders, Sôda and Sugimura, while those after WWII do not often record them. One reason is due to the impact of what became known as “modern economics" (kindai keizaï gaku 近代経済学), a complex, even bizarre mix, of mathematical economics and econometrics. In the spirit developed by the journal Econometrica, the science of economics became "mathematized". But that was not all there was in "modern economics" while in Japan, all that could be seen as the alternative to Marxism was gathered under this one name. Notice that there were also Marxian attempts at modelling prices and mathematized Marxism counted internationally famous Japanese scholars like Michio Morishima (who had been the student of Yasuma Takata). The nonMarxist approach was a mix of Keynesianism macroeconomics and microeconomic modelling with the underlying feeling was that mathematical economics should bring out the similarities of all these "new" currents. In any case, times were changing and philosophy was 
blindly rebuked. The most striking sign of its loss was the allegiance to plain instrumentalism in the style of Friedman's 1953 essay, a minimal economic methodology that bore upon positivist views already outdated in the eyes of professional philosophers. The gap between economists and philosophers was widening.

In our times, in the $21^{\text {st }}$ century, the perspective drawn by Sôda and Sugimura is still capable of sparking a revival of economic philosophy according to Shionoya. The prospects may look good since the guidelines were set and times of crisis in economics call for a revitalized interest in conceptual thinking. We refer the reader to Shionoya's texts, providing here the following quote:

Let us notice that Kantian constructivism, as Rawls developed it, appeared in the United States without any relationship to the German tradition that had existed after Kant himself. We therefore conclude that the in-depth work that Sôda and Sugimura had thought of were absolutely original contributions to social post-Kantian philosophy which we have largely demonstrated in the previous pages. This deserves all the more our attention in an ethical framework since it is the 'perfectionist' views that Sôda formed in a systematic theory of values that join in a prevailing value within the frame of the world of culture. The task to relate an ethics of 'justice' with an 'ethics' of 'virtue' from a Kantian basis, this indeed was a major project, that one may still consider as paradigmatic nowadays. It is in this way that economic philosophy was thus born in Japan, after being impregnated with Neo-Kantian thinkers, and it certainly has not come to an end, like a flower that would fruitlessly fade into the air. Quite the contrary, since the undertaking [of these two Japanese economists] allowed to display the whole potential of their basic scheme in the Kantian perspective, still nowadays capable of development. This is why we may indeed set the ideas by Sôda and Sugimura at the very origins of Japanese economic philosophy, as we are convinced that their plans are deemed to succeed and develop further in the present and future ${ }^{33}$.

This was written after 2000 , and it set a task for this $21^{\text {st }}$ century.

In any case, in Japan like in the West, the crises that economic theories fail to mend are cause that more and more academics debate models that were once taken for granted, and that reflexive attitude is what economic philosophy promotes. Times are indeed changing, hopefully towards a more favorable stance on "economic philosophy". If one follows the hope that Shionoya formulated, this special issue is one sign that a "revival of economic philosophy" is occurring in Japan.

This also suggests that this presentation shall not end without questioning what the stakes for economic philosophy in the present context may be. Europeans and the Japanese seem to have serious reasons to share some values. The difference with the times of Nakae and Nishi is that nowadays exchange is mutual: envoys go both ways and Japan is not merely importing values and ideas from the West, but exporting some to the West.

\section{The stakes today: economic philosophy and liberal norms between Europe and Japan}

In previous encounters between East and West, so to speak, some strange behaviors could be observed - such as Westerners adopting some customs, and even at times clothing outdated for the local Japanese, who in turn were keen to "Westernize" their lifestyles. On the side of Westerners, sometimes they were in admiration of their Japanese counterparts (to the

\footnotetext{
${ }^{33}$ See the final page of the text on Sôda and Sugimura by Shionoya in this volume. Our translation in English from the French translation (checked against the original Japanese).
} 
point of being naïve), while other times they were paternalistic (sympathetic, at best) or downright racist (in the worst case).

Such attitudes cannot, however, be upheld any longer. They were partly endorsed by naïve newcomers to Eastern Asia, but also by scholars of two categories: either favorably biased admirers or arrogant paternalists. In the $21^{\text {st }}$ century, these categories of Westerners will vanish among erudite scholars, if not fully among the increasing number of tourists visiting Japan. We, scholars, now connect as equals, and this is one outcome that the rising economic power in Eastern Asia has achieved. The times of Nakae and Nishi are long gone for our Japanese counterparts as well. Self-confidence is now widely shared; rather, what remains of boldness or shyness depends more directly on individual characteristics rather than on cultural traits or specificities. What is coming, and what must come, is a new type of scholar, who fits the global need for education and knowledge: on both sides, such scholars are "masters of their trade" and teach their disciplines as specialists of philosophy, law, sociology or economics, rather than of some under-determined "Asian studies".

In this issue of the Revue de philosophie économique/Review of Economic Philosophy, the contributors debate with their counterparts on even ground in a world of global knowledge. The word keizaï tetsu-gaku remains clear in Japanese vocabulary today, even though its contents must be re-explained in a contemporary context, much like Sôda and Sugimura had to do. In a sense, half a century of "modern economics", following the end of WWII, had the paradoxical effect of science regressing in its understanding of some fundamental notions.

Today, it is therefore necessary to re-introduce a few conceptual issues, which would not have received attention outside of a context of crisis. The stakes of economic philosophy are that we must deal once again with the consequences of not only a financial crisis, but also a crisis of social, moral, political and economic values. Post-WWII history made Japan the main ally of the US in the Asia-Pacific region: Japan pledged allegiance to the United States and has bases to this day harboring the $7^{\text {th }}$ Fleet of the US Navy: this has not (yet) been put into question (except locally, like in Okinawa with special difficult relationships).

However, the general framework is no longer post-Cold War, but post-post-Cold war (that is post-US hyper-hegemony), due to marked changes in US foreign policy, as well as to increasing challenges posed by China and so-called BRICS countries. This has unleashed trends that question liberal values anchored in European traditions and adopted, to a large extent, as a consequence of the century and a half of import/adoption/adaptation of European economics and philosophy by the Japanese, as briefly evoked in this introduction.

As an illustration, let us mention that relations between the European Union and Japan have reached a promising point as the EU and Japanese authorities concluded in July 2018 the world's largest Free Trade Agreement. This is worth keeping in mind while reading a journal issue such as the one the reader presently holds in hand. Is this agreement a turning point? That is for future history to say. Clearly, this Agreement aims to defend liberal ideas, while anti-liberalism is on the rise, as some contributors of this issue stress. The role of economic and socio-political norms must be highlighted with regard to what Europeans and the Japanese share, given their history of interaction, as summarized in the previous two sections of this introduction.

If the lessons of adoption/adaptation of Western, European-originated ideas in Japan are the active framework within which common views for the present world are rising, then we may ponder such queries as the following: is economic pressure still the main driving force for the import of foreign ideas? Could the exchange become reciprocal, particularly as ideas born in Japan find a way to renovating older patterns, for instance so-called "liberal" patterns? How can some signs of economic crisis that regularly surge in liberal capitalism be confronted? Answers to recurrent crises require focusing on economic development, with a comparative analysis of the different contexts in which it is displayed in Eastern Asia: what 
are the different ways to interpret Japanese, Korean and Chinese modernization, and which elements embedded in those cultures shall we retain (Campagnolo 2016a)? To give an example, the influence of the legal framework on mid- and long-term trade is of interest to law and economics and to the history of economic thought, but also to economic philosophy (Debin and van Zanden 2011).

The EU-Japan agreement is presently nothing less than the world's largest Free Trade Agreement. It is called an Economic Partnership Agreement (EPA) and is accompanied by a Strategic Partnership Agreement (SPA), legally binding, which mandates political and security cooperation. The conclusion of these agreements is timely, coming as they do in the shadow of a crisis of liberalism, punctuated by the rise of China and the US presidency of Donald Trump. At a strategic global level, the conclusion of these two agreements may raise the question of whether the EU and Japan can effectively exert joint global leadership to help maintain a liberal international order.

For instance, Japanese Prime Minister Shinzô Abe promotes "Pro-active Pacifism" and "Values Diplomacy" in foreign policy, critiquing previous policy that he claims as merely professed peace while doing little to promote it. This "Values Diplomacy" asserts that Japan will promote the values of liberal democracy, human rights, and the rule of law. Given that the EU is also actively promoting such values, these Abe administration policies apparently promise greater EU-Japan political and security cooperation. Whether the Abe administration's implementation of these two new policies really portends greater cooperation, or whether they are merely tactical responses to China's rise that offer little potential for expanding EU-Japan cooperation, such are the issues that political scientists and statesmen themselves must assess ${ }^{34}$.

One task of economic philosophy in practice may clearly be to help define and question the fundamentals of international. Our journal is concerned with a longer perspective, which started, as mentioned above, in the 19th-century disciplines such as the German philosophy of the German modernization era (the so-called Gründerjahre), French sociology (in the style of Auguste Comte or Émile Durkheim) and British "Manchesterianism", among other currents of thought.

The Japanese modernization process acts as a sifting and sieving mechanism. It thus was first in the nineteenth century to raise debates in Eastern Asia with symmetric conceptual traits to those within European systems. It still does. This resulted, and still results in comparisons between, on the one hand, Japan adopting some kind of "community style liberalism", somehow embedded in Japanese group culture and illustrated in the local practices of the Welfare state later, and on the other hand, a European concept of 'Markt sozialwirtschaft' originated in a more Continental European view, as its German-oriented name suggests enough. ${ }^{35}$ If modernization in Eastern Asia, and specifically in Japan, was never merely a copy of European powers and doctrines, Europe nevertheless set the tone with its "culture of growth" based on innovation in science and governance. ${ }^{36}$

Typical traits are conveyed in modernizing countries according to their own "civilizational style", and this is what so-called "Modernization Theory" has endeavored to study. Where such studies meet the framework of economic philosophy, they shall also be useful ${ }^{37}$ to

\footnotetext{
${ }^{34}$ This is what, among many others, Paul Midford, a Professor and Director of the Japan Program at the Norwegian University of Science and Technology (NTNU) in Trondheim, investigates. Let us mention his presentation "The EU-Japan Partnership in the Shadow of China: The Crisis of Liberalism", given on February 5, 2019, at the International Center for Asian Studies (Temple University, Japan Campus, Tokyo).

${ }^{35}$ This topic deserves more space than can be granted here. Regarding the building of an "economic nation" in Germany from the criticisms of political economy, see (Campagnolo 2010) in an immense body of literature.

${ }^{36}$ See the eponymous volume by Joel Mokyr (2017): the Review of Economic Philosophy schedules a bookreview in an upcoming issue as a French translation is scheduled by Paris publishing house Gallimard.

${ }^{37}$ For a survey of this literature, see (Gharbi 2016).
} 
readers of the present thematic issue. Individualistic theories may diverge deeply from an anthropological, or civilizational, point of view, but there exist genuine Eastern Asian types of such individualistic approaches beyond the cliché of "group culture" already mentioned. In that sense, are individualization and liberalization on a par? This is one question for economic philosophy as well (see Campagnolo, 2016a, part II: 109-186).

Economic philosophy comes in to challenge commonplace views and debate representations, to question what civilizations share with respect to rationalism, individualism and liberalism (pros and cons), values and norms. The Europeans set forth these norms and values, which the Japanese picked up as they modernized. What both sides seem to need now is to reassess them together. Comparative studies of economic and philosophical doctrines and their reception/transfer illustrate this perspective, which is for economic philosophy to contemplate. The present issue is one such example for readers to enjoy.

\section{References}

Altobrando, A. 2016. "The Essence of Individuality in Kitarô Nishida's works: a Contribution from Eastern Asia to a transcultural Understanding of the Meaning of Individualism" in Campagnolo, G. (Ed.), Liberalism and Chinese Economic Development, Abingdon and New York: Routledge: 111-130.

Blocker, G. H. and C. L. Starling. 2001. Japanese Philosophy, Albany: State University of New York Press.

Campagnolo G.

- 2010. Criticisms of Classical political economy. Menger, Austrian Economics and the German Historical School. Abingdon and New York: Routledge.

- (Ed.) 2016a. Liberalism and Chinese Economic Development: Perspectives from Europe and Asia, Abingdon and New York: Routledge series "Frontiers in the World Economy".

- 2016b. "Hayek au Japon: la réception d'une pensée néolibérale", Revue de philosophie économique/ Review of Economic Philosophy, 17/1 : 171-208.

Dalissier M., Nagai S. and Y. Sugimura. 2013. Philosophie japonaise : le néant, le monde et le corps, "Textes clés de philosophie japonaise", Paris : Vrin.

De Barry, T., Gluck C., Gluck T., and E. Arthur. 2001-2006. Sources of Japanese Tradition, vol. III: From 1600 to 2000, part 2 (1868 to 2000), New York: Columbia University Press.

Dufourmont, E. 2009. The Spirit of Nakae Chômin and the 'Philosophy of Joy'. In Takahiro Nakajima (Ed.), Whither Japanese Philosophy? Tokyo: University of Tokyo Center for Philosophy booklets.

Gharbi, J.-S. 2016. "Modernization Theory, Chinese Modernization and Social Ethics" in Campagnolo, G. (Ed), Liberalism and Chinese Economic Development, Abingdon and New York: Routledge: 86-106.

Heisig J. W. and M. Uehara (Eds.) 2008. Frontiers of Japanese Philosophy. III: Origins and Possibilities, Nagoya: Nanzan Institute for Religion and Culture.

Heisig, J.W. Kasulis T. P. and J. C. Maraldo. 2011. Japanese Philosophy: A Sourcebook, Honolulu: University of Hawaï Press.

Hori, V. S. and M. Curley (Eds.) 2008. Frontiers of Japanese Philosophy II. Neglected Themes and Hidden Variations, Nagoya: Nanzan Institute for Religion and Culture.

Ikeo, A. 2001. "History of Japanese Economic Thought: the Present and the Future", Annals of the Society for the History of Economic Thought, 39: 94-102.

Ma, D. and Luiten van Zanden, J. (Eds.) 2011. Law and Long-Term Economic Change. A Eurasian Perspective, Stanford: University Press.

Fukuzawa Y. 1876. Gakumon no Susume (A Call to Study), Tokyo (in Japanese).

Gordon, A. 2003. A Modern History of Japan. From Tokugawa Times to the Present, Oxford: Oxford University Press.

Han, S.-J. and Y.-H. Shim. 2016. "Dual Individualization in East Asia: individualization in society and in the family". In Campagnolo G. (ed.) (2016) Liberalism and Chinese Economic Development: Perspectives from Europe and Asia, Abingdon and New York: Routledge: 147-166. 
Koizumi, T. 1989. Nishi Amane to Ôbei shisô to no desai (Nishi Amane meets Western Thought), Tokyo: Mitsumine Shuppan (in Japanese).

Kumagai, J. 1998. "Enlightenment and Economic Thought in Meiji Japan: Yukichi Fukuzawa and Ukichi Taguchi". In S. Sugihara, T. Tanaka (eds) Economic Thought and Modernization in Japan, Cheltenham: Edward Elgar.

Lefebvre, A. 1884. La philosophie, Paris: Reinwald. Japanese)

Miyamura, H. 1989. Rigaku Chômin ("Chômin" the Philosopher), Tokyo : Misuzu shôbô (in

Mokyr, J. 2016. A Culture of Growth. The Origins of the Modern Economy. Princeton: Princeton University Press.

Morishima, M. 1984. Why has Japan Succeeded? Western Technology and the Japanese Ethos, Cambridge: Cambridge University Press ( $1^{\text {st }}$ ed. 1982).

Routledge.

Morris-Suzuki, T. 1989. A History of Japanese Economic Thought, Abingdon and New York:

Nakae, C.

- 1983-1986. Nakae Chômin Zenshû (The Complete Works of Nakae Chomin), Tokyo: Iwanami Shoten (in Japanese) including:

○ Rigaku Kôgen (A. Philosophical Quest), vol. 7.

- Ichinen Yûhan (One Year and a Half), vol. 10: 125-200.

- Zoku Ichinen Yûhan (One Year and a Half. A Sequel), vol. 10: 221-292.

- 1984. A Discourse by Three Dunkards on Government (Sansuijin keirin mondo), Eng. tr. by Nobuko Tsukui and Jeffrey Hammond, Boston: Weatherhill, series "UNESCO Collection of representative Works - Japanese series". Japanese).

Nishi, A. 1862. Hyaku-ichi Shinshuu (One Hundred and One New Theories), Tokyo (in

Piovesana, G. K. 2013. Recent Japanese Philosophical Thought (1862-1996). A Survey. Richmond, Japan Library, $1^{\text {st }}$ ed. 1963. Reed. 1997 with a "new Survey" by Naoshi Yamawaki "Philosophical Thought of Japan 1963-1996", Abingdon and New York: Routledge.

Porter, Th. M. and D. Ross (Eds.) 2003. The Social sciences in Japan, Cambridge University Press.

Powelson, J. P. 1997. Centuries of Economic Endeavour. Parallel Paths in Japan and Europe and their Contrast with the Third World, Ann Arbor: University of Michigan Press ( $\left.1^{\text {st }} \mathrm{ed} .1994\right)$.

Schefold B. 2016. Great economic Thinkers from Antiquity to the Historical School. Translations from the series Klassiker der Naionalökonomie, Chap. 5 "Asian Classics - Japan”, Abingdon and New York: Routledge: 369-393.

Soyeda, J. 1893. The Study of Political Economy in Japan, Economic Journal, 3/10: 334-339. Routledge.

Sugiyama C. 1994. Origins of Economic Thought in Modern Japan, Abingdon and New York: 